DOI: https://doi.org/10.31073/mivg202001-224

Available at (PDF): http://mivg.iwpim.com.ua/index.php/mivg/article/view/224

UDC 631.431 .7

\title{
SOIL COMPACTION ASSESSMENT AS A MANIPULATIVE STRATEGY TO IMPROVE SOIL BIODIVERSITY: AN APPROACH FOR MEETING SDG TWO AND SIX
}

\author{
V.O. Chude ${ }^{1}$, E.E. Oku², G.I.C. Nwaka ${ }^{3}$, M.S. Adiaha ${ }^{4}$ \\ ${ }^{1}$ Registrar/CEO (Researcher/Scientist), Nigeria Institute of Soil Science (NISS); \\ https://orcid.org/0000-0002-9562-3571, e-mail: vchude@yahoo.co.uk, \\ 2 Researcher/Scientist, Department of Soil Science, University of Abuja; \\ https://orcid.org/0000-0002-5043-6457; e-mail: eessienoku@gmail.com; \\ ${ }^{3}$ Researcher/Scientist, Department of Soil Science, University of Abuja; \\ https://orcid.org/0000-0002-2293-4213; \\ ${ }^{4}$ Researcher/Scientist, Department of Planning, Research, Extension \& Statistics (PRES), NISS; \\ https://orcid.org/0000-0002-2645-3687; e-mail: mondaysadiaha@gmail.com
}

\begin{abstract}
The rapid increase in soil deterioration has been a drawback to global development, acting like a barrier to sustainability of Agriculture and the environment. Biodiversity in soil plays a crucial role in ecosystem sustainability, but yet there exist a rapid deterioration in soil biodiversity especially due to increase soil toxins, chemical spills, wind erosion including the rapid down-pour by rainfall which destroys soil structure and degrade soil biota. Soil compaction reduction manipulation through tillage and application of fertilizer plays a major role for food production, apart from being a part of environmental sustainability strategy. Field studies was conducted, where the status of soil compaction was examined, a replicate of four (4) soil sample were collected at a twenty (20) points sampling station using the proportionate stratified random sampling technique. Laboratory analysis output indicated high soil compaction. Laboratory analysis output was ranked with FAO standardize rate for compaction effect on soil biodiversity. Result of the finding indicated high soil compaction with bulk density value range of $1,56 \mathrm{gcm}^{-3}-2,71 \mathrm{gcm}^{-3}$ which was found to be too compact for sustainable soil biota development. And porosity value range of $1 \%-41 \%$ was obtained, which indicated tight soil spore that can imped soil biodiversity. Correlation analysis $\left(R^{2}\right)$ revealed a positive correlation between topography and soil compacting, with a ranking output of the soil been poor in biodiversity (biota load). Outcome of this investigation concluded that proper tillage, application of fertilizer including organic matter be carried out for the study area soils and soils of its environs.
\end{abstract}

Key word: biodiversity, soil sustainability, soil compaction, global development, SDG.

\section{Introduction}

Humankind has suffered many hazard cause by nature and anthropogenic elements. Among soils many disturbances affecting global development is the compaction of soils and it current and anticipated effect on soil biodiversity. Building upon this, one can quickly say soil biota plays a crucial role in the ecosystem regulation and balance. The sealing and compaction of the topsoil plays a detrimental role in the sustainability of the environment and for sustainable crop production.

Soil physical properties pays a curial role in the regulation of the eco-system and soil biodiversity including climatic regulation (Hillel, 2004; Oku et al., 2010; Adiaha et al., 2020). Bulk density presents the ability of the soil being able to allow plant root penetration for nutrients and water absorption. Porosity presents the status of the space between the different soils layers as it appear in the peds. These two physical properties of the soil presents the status of the soil in regards to its ability for plant root penetration, growth and development, soil biodiversity, sustainability and water the soil ability for water regulation, aquifer recharge, soil infiltration including the engineering utilization of the soil.

Understanding the distribution and properties of soils is necessary to planning and implementing sustainable land use and/or rehabilitation of degraded lands (Ali et al., 2010). Knowledge about the properties of soils can be generated directly through field observation, though soil properties are extremely variable in space and time (Korres et al., 2013). A better mechanism for predicting adequate and yet reproducible soil information is by using proxy lands' biophysical and climatic characteristics that have established strong relationships with soil properties (Fantaw et al., 2006; Moore et al., 1993). Several studies have been conducted to determine dominant controlling factors of soil properties on the land- 
scape (Brubaker et al., 1993; Fantaw et al., 2006; Miller et al., 1988; Mulugeta and Sheleme, 2010; Sheleme, 2011; Wang et al., 2001). For instance, Wang et al. (2001) regarded topography as the dominant factor influencing soil property variation due to its influence on runoff, drainage, soil biodiversity, microclimate and soil erosion, and consequently on soil formation under a hill slope in semi-arid small catchment of the loess plateau of China. Similarly, Mulugeta and Sheleme (2010) recounted that most of the important soil quality indicators were affected by different landscape positions, particularly at the surface horizons. Significant variation in soil properties with respect to aspect and vegetation communities were also noticed by Fantaw et al. (2006) in the highlands of southeastern Ethiopia. Moreover, many soil properties including particle-size distribution, bulk density, soil biota, $\mathrm{pH}$ and organic matter content vary with slope position (e.g., Miller et al., 1988; Mulugeta and Sheleme, 2010; Sheleme, 2011; Wang et al., 2001). A common denominator of all these studies is a demonstrated strong relationship among topographic positions, soil properties and vegetation composition, such that the distribution of a particular soil property may vary with topographic attributes, soil biota population and vegetation types. Understanding the dynamics and distribution of the soil characteristics as influenced by landscape or topographic features is critical for assessing the effect of future land use changes on soil use and management (Kosmas et al., 2000).

Soil biodiversity reflects the variability among living organisms including a myriad of soil micro-organisms (FAO, 2000), such micro-organisms (bacteria, fungi, protozoa including nematodes) and meso-fauna (e.g. acari and springtails), as well as the more familiar macrofauna (earthworms and termites). Plant roots can also be considered as soil organisms in view of their symbiotic relationships and interactions with other soil components (FAO, 2000). These diverse organisms interact with one another and with the various plants and animals in the ecosystem forming a complex web of biological activity (FAO, 2000; Adiaha, 2016 b). Ecological functions and soil biodiversity are important because of their role in: structure formation, stability of structure and functions, fertility, buffering and in providing possibilities to have the soil acting as a carbon sink (Breure, 2004).

Soil organisms contribute a wide range of essential services to the sustainable function of all ecosystems (Penn State Extension, PSE, 2003; FAO, 2000). They act as the primary driving agents of nutrient cycling, regulating the dynamics of soil organic matter (FAO, 2000), soil carbon sequestration and greenhouse gas emission, modifying soil physical structure and water regimes, enhancing the amount and efficiency of nutrient acquisition by the vegetation and enhancing plant health (FAO, 2000; PSE, 2003). These services are not only essential to the functioning of natural ecosystems but constitute an important resource for the sustainable management of agricultural systems.

Soil organisms act as the primary driving agents of nutrient cycling, regulating the dynamics of soil organic matter, soil carbon sequestration and greenhouse gas emission, modifying soil physical structure and water regimes, enhancing the amount and efficiency of nutrient acquisition by the vegetation and enhancing plant health (FAO, 2000). The air we breathe, the water we drink and the food we eat all rely on biodiversity. It is fundamental we produce food in a way that preserves the environment. That is why safeguarding natural resources and biodiversity is critical to human-livestock health and planetary wealth (FAO, 2000, FAO, 2006; Barros, 1999; Hågvar, 1994; McNeely et al., 1995). Sustainable agriculture is the answer to reverse trends that lead to biodiversity loss. Soil biodiversity and soil health can be seen as one measure of environmental quality, because the functioning of the soil system may be the key to understanding the health of agroecosystems.

The invasion and degradation of pastures due to biologically created soil compaction results in negative feedbacks to climate change in methane emission. Deforested area converted into pasture are usually degraded due to mismanagement, phytosanitary problems, poor soil fertility and soil structural modification (linked to soil macro-invertebrate activity including). When the forest is converted to pasture, the use of heavy machinery and, later, cattle trampling lead to severe soil compaction, particularly in the 5-10 cm layer, impeding root development and hydrological processes in the soil (Barros, 1999; Hågvar, 1994; McNeely et al., 1995). In most deforested lands and land converted to other uses not fully utilized, the native soil macro-invertebrate communities are radically and drastically depleted, i.e. most of the native taxa (morphospecies) disappear. An opportunistic invading earthworm (Pontoscolex corethrurus (Müller); Glossoscolecidae) benefits from anthropic disturbances and occupies the empty niche left by native earthworms and soil macrofauna, increasing its biomass to more than $450 \mathrm{~kg} / \mathrm{ha}$ equivalent to nearly 90 percent of total soil macro-invertebrate biomass (Juan, 1999). When $P$. corethrurus is present in the forest 
there is no negative effect on the native species communities, which have similar or higher densities in the presence of $P$. corethrus. (Juan, 1999) suggests that this invasive species, unlike native species, is able to feed and develop in environments where litter resources are decreased.

Juan (1999) showed that $P$. corethrus can produces more than $100 \mathrm{t} / \mathrm{ha}$ of castings, dramatically decreasing soil macroporosity down to a level equivalent to that produced by the action of heavy machinery on soil $\left(2.7 \mathrm{~cm}^{3} / 100 \mathrm{~g}\right)$, whereby during the rainy season these casts plug up the soil surface, saturating the soil and producing a thick muddy layer, where anaerobic conditions prevail (increasing methane emission and denitrification). In the dry season, desiccation cracks the surface and the inability of roots to extract water from the soil causes plants to wilt and die, leaving bare patches in the field. The report of (Juan, 1999; FAO, 2000, FAO, 2006; Barros, 1999; Hågvar, 1994; McNeely et al., 1995) have presenting a view that some soil invertebrate species may bring catastrophic consequences to soil ecosystem functioning by increasing greenhouse gas emissions from soils and increasing soil compaction, apart from being a blessing to soil fertility and increase crop production.

Soil compaction has been reported by Radford et al (2001) to have impaired soil biodiversity population, Radford et al (2001) data presented by Radford et al., (2001) including FAO (2006) indicated a view that with increase in soil compaction due to certain phenomena that gears soil compaction, soil diversity could be heavily depleted, which could stand like a hindrance to soil fertility and sustainability.

Further report by USDA (1999) indicated that high bulk density is one of the major factors gearing depletion of soil biodiversity. The study of USDA (1999) further stated statistical value (Table 2) at which bulk density becomes too compact that inhibit root penetration, which also gives a view that at this point the soil biodiversity population impaired and almost completely depleted.

1. Ideal and root-restricting bulk densities with biodiversity impact.

\begin{tabular}{|l|c|c|l|}
\hline \multicolumn{1}{|c|}{ Soil Texture } & $\begin{array}{c}\text { Ideal bulk density } \\
(\mathrm{g} / \mathrm{cm})\end{array}$ & $\begin{array}{c}\text { Bulk density restricts } \\
\text { root growth }(\mathrm{g} / \mathrm{cm})\end{array}$ & \multicolumn{1}{|c|}{ Impact on Soil Biodiversity } \\
\hline Sand, loamy sand & $<1.60$ & $>1.80$ & $\begin{array}{l}\text { Impaired soil biota (biodiversity) } \\
\text { population growth, compacted soil }\end{array}$ \\
\hline Sandy loam, loam & $<1.40$ & $>1.80$ & $\begin{array}{l}\text { Impaired soil biota (biodiversity) } \\
\text { population growth, compacted soil }\end{array}$ \\
\hline $\begin{array}{l}\text { Sandy clay loam, } \\
\text { clay loam }\end{array}$ & $<1.40$ & $>1.75$ & $\begin{array}{l}\text { Impaired soil biota (biodiversity) } \\
\text { population growth, compacted soil }\end{array}$ \\
\hline Silt, silt loam & $<1.30$ & $>1.75$ & $\begin{array}{l}\text { Impaired soil biota (biodiversity) } \\
\text { population growth, compacted soil }\end{array}$ \\
\hline Silty clay loam & $<1.40$ & $>1.65$ & $\begin{array}{l}\text { Impaired soil biota (biodiversity) } \\
\text { population growth, compacted soil }\end{array}$ \\
\hline $\begin{array}{l}\text { Sandy clay, silty } \\
\text { clay }\end{array}$ & $<1.10$ & $>1.58$ & $\begin{array}{l}\text { Impaired soil biota (biodiversity) } \\
\text { population growth, compacted soil }\end{array}$ \\
\hline Clay & $<1.10$ & $>1.47$ & $\begin{array}{l}\text { Impaired soil biota (biodiversity) } \\
\text { population growth, compacted soil }\end{array}$ \\
\hline
\end{tabular}

Source: USDA. (1999); FAO (2006)

2.General Porosity Ranking

\begin{tabular}{|l|c|}
\hline \multicolumn{1}{|c|}{ Soil porosity status indicator } & Rating (\%) \\
\hline Soil very compact & $<5 \%$ \\
\hline Soil compact & $5-10 \%$ \\
\hline Soil moderately porous & $10-25 \%$ \\
\hline Soil highly porous & $25-40 \%$ \\
\hline Soil extremely porous & $>40 \%$ \\
\hline
\end{tabular}

Source: (Pagliai, 1988)

Slope gradient is a key factor in influencing the relative stability of a slope including soil biota (USDA, 1999). It determines the degree to which gravity acts upon a soil mass. Slopes are often irregular and complex, with gradients varying greatly throughout a given shoreline profile (Greenbelt Consulting, 2014). The Food and Agricultural Organization of the United Nations (FAO, 2006) presented a ranking for slope gradient, as shown in Table 3.

Against the huge impact of soil compaction on soil sustainability, the present study seeks to:

1. Assess soil compaction interaction with topography

2. Assess soil compaction interaction with soil biodiversity 
3. Slope gradient Class and Rating

\begin{tabular}{|c|l|c|}
\hline Class & \multicolumn{1}{|c|}{ Description (Rating) } & $\%$ \\
\hline 01 & Flat & $0-0.2$ \\
\hline 02 & Level & $0.2-0.5$ \\
\hline 03 & Nearly Level & $0.5-1.0$ \\
\hline 04 & Very gently slopping & $1.0-2.0$ \\
\hline 05 & Gently sloping & $2-5$ \\
\hline 06 & Sloping & $5-10$ \\
\hline 07 & Strongly sloping & $10-15$ \\
\hline 08 & Moderately steep & $15-30$ \\
\hline 09 & Steep & $30-60$ \\
\hline 10 & Very steep & $>60$ \\
\hline
\end{tabular}

Source: FAO (2006)

\subsection{Materials and methods}

\subsection{Geography of the Study Area}

University of Abuja landmass falls within Gwagwalada. Gwagwalada is a suburb of the Federal Capital Territory, Nigeria. It is situated along Abuja-Lokoja road at about 55 kilometers away from Federal Capital Teeritory main town. The area lies between latitudes $8^{\circ} 55^{\prime} \mathrm{N}-9^{\circ} 00^{\prime} \mathrm{N}$ and longitudes $7^{\circ} 00^{\prime} \mathrm{E}-7^{\circ} 04^{\prime} \mathrm{E}$ (Ishaya, 2013). The area is bordered by Kuje area council to the East, Abaji area council to the West, Kwali area council to the south and Abuja Municipal Area Council to the Northeast and to the North by Suleja Local Government Area of Niger State (Balogun, 2001).

\section{Soils of the Area}

The soils of the area is refered to as "hardpan soils" with crystalline lattice nature (in terms of minerals) (Balogun, 2001)

\section{Temperature of the Area}

Gwagwalada has recorded a mean maximum monthly temperature ranges between $28^{\circ} \mathrm{C}-30^{\circ} \mathrm{C}$ and the mean minimum monthly temperature ranges between $25^{\circ} \mathrm{C}-27^{\circ} \mathrm{C}$ (Balogun, 2001)

\subsection{Sampling Techniques}

The proportionate stratified random sampling technique was used to delineate the point where soil sampling was carried out.

\subsection{Soil compaction Influence on Biodiversity Ranking}

Soil compaction indicators was ranked with the standardized estimates presented by FOA (2006) and USDA. (1999) to obtain the impact of soil compaction on soil biodiversity.

\subsection{Reconnaissance survey}

Reconnaissance survey was carried out, where sampling points were delineated using the proportionate stratified random sampling. A mapping unit was obtained from were interpolation was done using GIS to cover for the whole of University of Abuja terrain. This was done at a scale of 1:20000.

\subsection{Global Positioning System (GPS) / Geographic Information System (GIS) Modelling}

Area covered by the study was geo-referenced using Global Positioning System (GPS) hand device and further processed using Quantum Geographic Information System (GIS), where base map for the study area landmass and study frame was developed

\section{Soil Biodiversity Studies}

Soil samples collected at all the 20 points of experiment was viewed in a micro-morphological microscope and hand lens to examine the population of soil biota. This was done at moist condition of the soil.

2.6Soil sampling: A replicate of four (4) soil sample were collected at a twenty (20) points sampling station using the proportionate stratified random sampling technique. Sampling was done using soil core at a depth of $0-30 \mathrm{~cm}$. Soil samples were oven dried and used for the determination of bulk density and porosity.

\subsection{Laboratory Analysis}

- Bulk density Determination

Bulk density $(B d)$ of the soil was determined following the core method as described by Grossman and Reinsch (2002), using the equation:

$$
\text { Bulk Density }(B d)=\frac{\text { Mass of oven dry soil }(\mathrm{g})}{\text { Volume of } \operatorname{soil}(\mathrm{cm})} 1.1
$$

- Total Porosity was calculated from result of bulk density using equation 1.1 From the bulk density value obtained, the Porosity of the 
soil was determined following Gee and Bauder (1986) procedure, using the equation:

$$
\operatorname{Total} \text { Porosity }(T P)=\left[1-\frac{B d}{P d} \times 100\right],
$$

where $P d=$ particle density $\left(2.65 \mathrm{~g} / \mathrm{cm}^{3}\right)$. Value used for particle density was a standardized value presented by Oku et al., (2010) for tropical soils, and soils of Abuja

$B d=$ Bulk density . $100=$ Constant

\subsection{Statistical Analysis}

The correlation statistics was used to assess the relationship between soil compaction and topography, with it implication on biodiversity. The coefficient of determination $\left(\mathrm{R}^{2}\right)$ was utilized to find the statistical relationship. Percentage analysis was utilized to find the percentage influence of the interaction among variables.

\subsection{Results and discussion}

3.1 Topographic and soil compaction indicators Assessment for soil diversity impact

Result of data analysis presented Table 5 indicated that at a slope gradient of $2.84 \%$ (Site 1) the soil compaction indicator using the bulk density was observed at $2.1 \mathrm{gcm}^{-1}$ which indicated that the soil has serious limitation to enhance the population of microbial in the soils, presenting a view that such soil needs ecological including agronomic remedy to function well for crop production and ecological balance. At Site 2, a topographic potential (slope gradient) was obtained at $2.64 \%$ with bulk density value of $2.0 \mathrm{gcm}^{-1}$ which presents the soil as been compact, and as a hindrance to microbial development within its layers. A topographic slope gradient of $2.61 \%$ was obtained for Site 3, with a bulk density value of $2.9 \mathrm{gcm}^{-1}$, presenting a view that the soil is compact, hence having the potential of reducing soil microbial population and adversely affecting soil biodiversity. A topographic percentage value of 2.6 was obtained for Site 5 , with a bulk density value of $1.63 \mathrm{gcm}^{-1}$ which indicated a view that the soil is compact with an impact of impairing soil biodiversity, increase methane greenhouse gas emission, with anticipated long term effect on soil hardening, swollen and contraction. At Site 6 a topographic influence of $2.52 \%$ was obtained, this followed a bulk density value of $2.27 \mathrm{gcm}^{-1}$ was found to be too compact for productive multiplication of soil biota. Site 7 recorded a soil compaction value at $2.41 \mathrm{gcm}^{-1}$ with a topographic gradient of $2.69 \%$ which indicated a view the point of sampling is a gentle slope position according to the ranking of
FAO (2006). Result of data analysis presented in Table 3 indicated a view that Site 8 has a sloping class of (05) which is a gentle slope, while producing a value at $2.75 \%$. It was observed that Site 8 has a bulk density value of $2.19 \mathrm{gcm}^{-1}$ which was ranked to be too toxic for soil biodiversity development. Site 9 was found to have a slope gradients value of $2.78 \%$ which presented the point as a gentle slope, with a slope class of $($ Class $=05)$. Bulk density of the site was found to be 2.07 which presented the site has been to compact for soil biodiversity development. Site 10 recorded a topographic value at $2.89 \%$ which indicated the site as been classified under the gentle slope class $($ Class $=05)$. The bulk density at Site 10 recorded a value at $2.5 \mathrm{gcm}^{-1}$ which was found to be too toxic for soil biota and biodiversity functionality. Site 11 recorded a slope class at $(2.93 \%$ which falls under the Class $=05)$ which was ranked to be a gentle slope, with a soil compaction indicator of $1.73 \mathrm{gcm}^{-3}$, presenting a view that the soils are toxic and has an impediment for root penetration and soil biodiversity development. Research data analysis outcome presented a view that Site 12 is a gentle sloping terrain with a topographic value of $2.83 \%$ which was ranked to be under the Class 05 sloping type. The soil compaction status (bulk density = $2.19 \mathrm{gcm}^{-3}$ ) at

Site indicated a view that the soil is compact with a hindering potential for soil biota development. It was observed that Site 13 produced a topographic position at a value of $2.75 \%$, which was ranked to gentle slope with a slope class of $(\mathrm{C}=05)$, indicating a view that the area is prone to environmental influence with associated soil compaction problems due to increase variability in the climate. This view meets-up with the laboratory analysis outcome which presented the soil as been compact, hence has a strong potential in hindering soil biodiversity. However, a soil compaction indicator using the bulk density revealed a value of $2.67 \mathrm{gcm}^{-1}$ which was found to be too toxic for soil biodiversity development. A topographic potential at $2.82 \%$ was observed for Site 14, which presented the site as been a gentle slope, with a slope class $(\mathrm{C}=05)$. The soil compaction status of the site was found to $2.45 \mathrm{gcm}^{-1}$ which was ranked to be a limiting point for root penetration including soil biodiversity development. A statistical value of $2.88 \%$ was recorded as the topographic potential at Site 15 , indicating that the area is a gentle slope, which fall under the slope class of $(\mathrm{C}=05)$, presenting a view that the area is vulnerable to wind erosion includingothercommonnaturalandanthropogenic hazards that affect flat terrain. The soil compac- 
tion status of this site (Site 15) was found to be $1.56 \mathrm{gcm}^{-1}$ which indicated the soil is very compact, and hence can immensely impaired soil biodiversity development. Similar trend was observed for Site 16 which recorded a topographic position at $2.84 \%$, with implication of the site been a gentle slope and falling under the slope class of $\mathrm{C}=05$. However, soil bulk density value of $2.18 \mathrm{gcm}^{-1}$ was obtained for Site 16, with an indication of the Site been compact, and hindering soil biota development. Site 17 recorded a value of $2.72 \%$ for the topographic influence, this result presented the site as been a gentle slope, with slope class of $(\mathrm{C}=05)$ indicating a view that the area is prone to environmental disturbances. The soil compaction status at this site was found to be $2.71 \mathrm{gcm}^{-1}$, which indicated view that the site has a strong soil compaction problem which can adversely hinder soil biodiversity development. Result outcome presented Site 18 as been a gentle slope, with associate slope class of $(2.77 \%$, which is $\mathrm{C}=05)$, indicating a view that the area is prone to water and wind erosion. Result output further indicated the soils at Site 18 to be compact for root penetration, and soil biota development, presenting a soil compaction indicator (bulk density to be $\left.2.31 \mathrm{gcm}^{-1}\right)$. It was observed that Site 19 produced a slope gradient value of $2.72 \%$, with the implication that the site is a gentle slope, with a 05 classification. The soil compaction indicator (bulk density $=2.34 \mathrm{gcm}^{-1}$, at this site indicated that the soils are too toxic in compacting status and can greatly hinder soil biodiversity development. Result of data analysis observed for Site 20 indicated that the soils are too toxic in terms of compaction for root penetration including soil biodiversity development, while presenting a bulk density value of $2.29 \mathrm{gcm}^{-1}$. The soil topographic potential was found to be $2.52 \%$, which indicated that the area is a gentle slope, with a slope class of $(\mathrm{C}=0.5)$ using the FAO (2006) ranking.

Result obtained for this research outcome agrees with the finding of FAO (2006), where her research outcome indicated gentle to undu-

5. Topographic and soil compaction indicators: A measure for soil diversity Assessment

\begin{tabular}{|c|c|c|c|c|}
\hline Location code & $\begin{array}{l}\text { *Topographic } \\
\text { Elevation (m) }\end{array}$ & $\begin{array}{c}\text { Slope gradient } \\
(\%)\end{array}$ & $\begin{array}{c}* \text { Bulk density } \\
\left(\mathrm{gcm}^{-1}\right)\end{array}$ & * Porosity $(\%)$ \\
\hline 1 & 284 & 2.84 & 2.1 & 21 \\
\hline 2 & 264 & 2.64 & 2 & 25 \\
\hline 3 & 261 & 2.61 & 2.19 & 17 \\
\hline 4 & 260 & 2.6 & 1.64 & 38 \\
\hline 5 & 256 & 2.56 & 1.63 & 38 \\
\hline 6 & 252 & 2.52 & 2.27 & 14 \\
\hline 7 & 269 & 2.69 & 2.41 & 9 \\
\hline 8 & 275 & 2.75 & 2.19 & 18 \\
\hline 9 & 278 & 2.78 & 2.07 & 22 \\
\hline 10 & 289 & 2.89 & 2.5 & 15 \\
\hline 11 & 293 & 2.93 & 1.73 & 35 \\
\hline 12 & 283 & 2.83 & 2.19 & 17 \\
\hline 13 & 275 & 2.75 & 2.67 & 1 \\
\hline 14 & 282 & 2.82 & 2.45 & 7 \\
\hline 15 & 288 & 2.88 & 1.56 & 41 \\
\hline 16 & 284 & 2.84 & 2.18 & 18 \\
\hline 17 & 272 & 2.72 & 2.71 & 2 \\
\hline 18 & 277 & 2.77 & 2.31 & 13 \\
\hline 19 & 272 & 2.72 & 2.34 & 12 \\
\hline 20 & 252 & 2.52 & 2.29 & 14 \\
\hline $\mathbf{X}$ & 27330 & 273 & 217 & 1885 \\
\hline STD & 12.11 & 0.12 & 0.32 & 11.24 \\
\hline CV (\%) & 4 & 4 & 15 & 60 \\
\hline SE & 2.71 & 0.03 & 0.07 & 2.51 \\
\hline
\end{tabular}

*Data was obtain from Department of Soil Science Postgraduate Thesis Research Data Reserve, University of Abuja $\mathrm{X}=$ mean, $\mathrm{SD}=$ Standard deviation, $\mathrm{CV}=$ coefficient of variability, $\mathrm{SE}=$ Standard error 
lating slope in sub-Sharan Africa. Findings of this study confirms the research outcome of Oku et al. (2010) where the authors reported soil compaction been a hindrance to physical phase suitability. Report of Hillel (2004) further validates the outcome of this research, where the author reported topography been an influence on soil formation and sustainability including soil biodiversity.

3.2 Correlation between topography and soil compaction (Bulk density)

Data analysis output presented in Figure 1 and Table 6 indicated a view that there exist a positive correlation between topography and soil compaction, as field data output indicated a $R^{2}$ value of $(0.0568)$ for topographic influence and $\left(R^{2}=0.1345\right)$ for bulk density influence. It was observed that percentage interaction influence of $(5.68 \%)$ was observed for topography and $(13.45 \%)$ obtained for bulk density as a soil compaction indicator. It could be stated that following the percentage analysis output soil compaction influence has a greater influence on topography. Result of this analysis agrees with the findings of FAO (2006) which stated soil compaction been a hindrance to soil physical and chemical sustainability, and also playing a curtail factor in a topographic influence of an area.

\subsection{Correlation between topography and} soil compaction (Porosity)

Result presented in Figure 2 and Table 7 indicated a view that there exist a positive correlation between topography and soil porosity (compaction indicator), as correlation analysis result indicated a $R^{2}$ value of $(0.0568)$ for topographic influence and $\left(R^{2}=0.135\right)$ for soil porosity influence. Percentage interaction influence of $(5.68 \%)$ was obtained for topography and $(13.45 \%)$ obtained for porosity as a soil compaction indicator. Following percentage analysis result, soil compaction (porosity) has a greater influence on topography. Result of this analysis agrees with the findings of FAO (2006) which indicated soil compaction acting like a hindrance to soil biological functionality, while playing a curtail role in topographic and environmental interaction

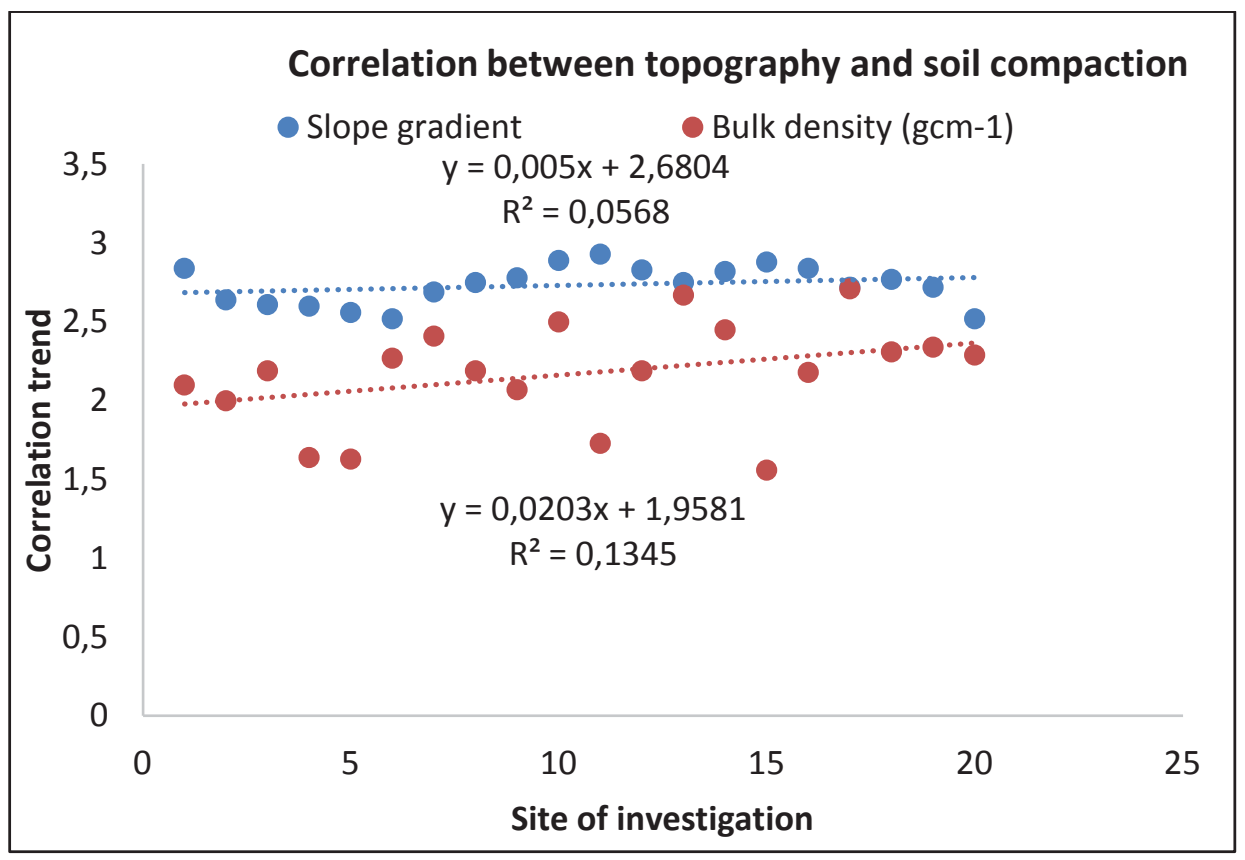

Fig. 1. Correlation between topography and soil compaction

6. Influence of Topography and soil Bulk density as a soil compaction indicator

\begin{tabular}{|c|c|c|c|c|c|}
\hline \multicolumn{3}{|c|}{ Topography } & \multicolumn{3}{c|}{ Bd (Soil Compaction Indicator) } \\
\hline $\begin{array}{c}\text { Coefficient of } \\
\text { Determination }\end{array}$ & $\mathrm{r}$ & \% Influence & $\begin{array}{c}\text { Coefficient of } \\
\text { Determination }\end{array}$ & $\mathrm{r}$ & $\%$ Influence \\
\hline 0.0568 & 0.24 & 5.68 & 0.1345 & 0.37 & 13.45 \\
\hline
\end{tabular}




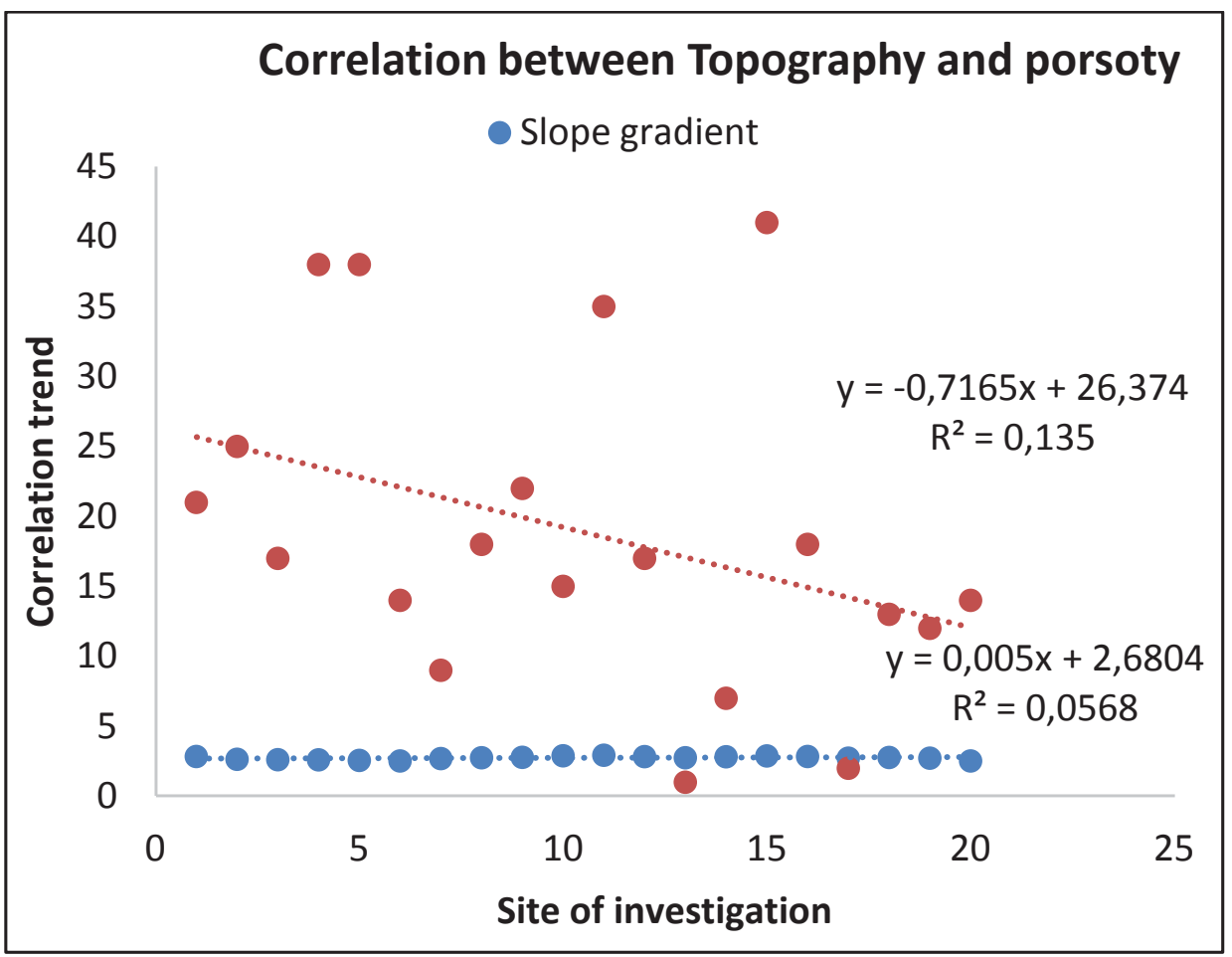

Fig. 2. Correlation between topography and soil compaction (Porosity)

7. Influence of Topography and soil porosity as a soil compaction indicator

\begin{tabular}{|c|c|c|c|c|c|}
\hline \multicolumn{3}{|c|}{ Topography } & \multicolumn{3}{c|}{ Porosity (Soil Compaction Indicator) } \\
\hline $\begin{array}{c}\text { Coefficient of } \\
\text { Determination }\end{array}$ & $\mathrm{r}$ & \% Influence & $\begin{array}{c}\text { Coefficient of } \\
\text { Determination }\end{array}$ & $\mathrm{r}$ & \% Influence \\
\hline 0.0568 & 0.24 & 5.68 & 0.135 & 0.37 & 13.5 \\
\hline
\end{tabular}

$\mathrm{r}=$ Correlation

3.4 Influence of Soil Compaction on Soil Biodiversity

Outcome of data analysis presented in Table 8, indicated a view that soil compaction adversely impaired soil biodiversity development. Following the standardized porosity ranking by Pagliai (1988), Site 1 soils (porosity = $21 \%$ ) was found to be moderately porous, with an implication of impaired soil biota population growth, which is an hindrance to productive crop production. A porosity value of $25 \%$ was obtained for Site 2, this site soil was ranked to be a moderately porous soil with implication of been an hindrance to soil biodiversity development. A porosity value of $17 \%$ was found to be associated with soils of Site 3 , which also presented the soil as been moderately porous with an ability of impaired soil biota population growth. At Site 4 . A porosity value of $17 \%$ presented the soil to be moderately porous, with an ability to adversely impaired soil biodiversity. Site 4 and Site 5 soils recorded a porosity value $38 \%$ which indicated the soil as been highly porous with implication of bee fair in biodiversity development, but still possess characteristics that could inhibit soil biodiversity development. At Site 6 a porosity value of $14 \%$ was obtained which indicated the soil as been moderately porous with soil biodiversity limiting tendency. At

Site 7 a $9 \%$ porosity value was obtained, were it was ranked to be a compacted soil that strongly impaired soil biota population growth. Site 8 recoded a porosity value of $18 \%$, a soil compaction ranking revealed that the soils at this site is moderately porous, still with a limiting ability for soil biodiversity development. Porosity value of $22 \%$ was obtained for Site 9, which presented a view that the site has a moderately porous soil, with a limiting tendency for soil biota development. Result of soil porosity analysis indicated that Site 10 soils are moderately porous, which was obtained at a value of $15 \%$. The implication of this view hold that the soils are hindrance to soil biodiversity development due to the compacted nature of the soils. A porosity value of $35 \%$ was obtained for Site 11 soils, this value 
obtained indicated a view that soils of the site are highly porous, and has a compaction problem, with associated biodiversity limiting factor. At Site 12 , the soils were ranked to be moderately compact (porosity $=17 \%$ ), with soil biota inhibiting factor due to the associated compacted status of its bulk density in the site. The soils at Site 13 where found to be very compact, and been a very poor soil in regards to soil biodiversity support and sustainable crop production. At Site 14 a porosity value of $7 \%$ was obtained, which revealed that the soil is a compacted soil with implication of been a hindrance to soil biodiversity development, environmental sustainability and crop production. A value at (porosity $=41 \%$ ) was obtained at Site 15 , which indicated that the soil is extremely porous revealed that the soil can to some extend support microbial development, but the compaction indices using bulk density gave a deep in-look where the soils of this site was found to be compact, and having characteristics that can inhibit the growth and development of soil biota. A porosity value of
$18 \%$ was obtained for Site 16 , which indicated that the soil is moderately porous, this indication presents a view that the soil could at least support microbial development, but it could be stated here that since an advance view into the level of compaction using the soil bulk density revealed that the soil is compact, then a valid statement that the soil has limiting characteristics for soil biodiversity development could be made. Soils at Site 17 was found to be extremely compact, with a porosity value of $2 \%$ been obtained, the implication of this finding is that the soils of this site could be a hindr5ance to sustainable food production, environmental sustainability, including soil diversity development. Porosity value at $($ Porosity $=13 \%$ for Site 18, Porosity $=$ $12 \%$ for Site 19 and Porosity $=14 \%$ for Site 20 ) was obtained, the range of this output indicated that the soils in these sites are moderately porous. Although a moderately porous soil can support certain threshold of soil microbial population and biodiversity, but it was found that since the bulk density of these soils indicated that the soils were

8. Influence of Soil Compaction on Soil Biodiversity

\begin{tabular}{|c|c|c|c|}
\hline $\begin{array}{l}\text { Location } \\
\text { code }\end{array}$ & $\begin{array}{c}* \text { Porosity } \\
(\%)\end{array}$ & $\begin{array}{l}\text { *Bulk } \\
\text { density } \\
\left(\mathrm{gcm}^{-3}\right)\end{array}$ & Impact on Soil Biodiversity \\
\hline 1 & 21 & 2.1 & Impaired soil biota (biodiversity) population growth, compacted soil \\
\hline 2 & 25 & 2 & Impaired soil biota (biodiversity) population growth, compacted soil \\
\hline 3 & 17 & 2.19 & Impaired soil biota (biodiversity) population growth, compacted soil \\
\hline 4 & 38 & 1.64 & Impaired soil biota (biodiversity) population growth, compacted soil \\
\hline 5 & 38 & 1.63 & Impaired soil biota (biodiversity) population growth, compacted soil \\
\hline 6 & 14 & 2.27 & Impaired soil biota (biodiversity) population growth, compacted soil \\
\hline 7 & 9 & 2.41 & Impaired soil biota (biodiversity) population growth, compacted soil \\
\hline 8 & 18 & 2.19 & Impaired soil biota (biodiversity) population growth, compacted soil \\
\hline 9 & 22 & 2.07 & Impaired soil biota (biodiversity) population growth, compacted soil \\
\hline 10 & 15 & 2.5 & Impaired soil biota (biodiversity) population growth, compacted soil \\
\hline 11 & 35 & 1.73 & Impaired soil biota (biodiversity) population growth, compacted soil \\
\hline 12 & 17 & 2.19 & Impaired soil biota (biodiversity) population growth, compacted soil \\
\hline 13 & 1 & 2.67 & Impaired soil biota (biodiversity) population growth, compacted soil \\
\hline 14 & 7 & 2.45 & Impaired soil biota (biodiversity) population growth, compacted soil \\
\hline 15 & 41 & 1.56 & Impaired soil biota (biodiversity) population growth, compacted soil \\
\hline 16 & 18 & 2.18 & Impaired soil biota (biodiversity) population growth, compacted soil \\
\hline 17 & 2 & 2.71 & Impaired soil biota (biodiversity) population growth, compacted soil \\
\hline 18 & 13 & 2.31 & Impaired soil biota (biodiversity) population growth, compacted soil \\
\hline 19 & 12 & 2.34 & Impaired soil biota (biodiversity) population growth, compacted soil \\
\hline 20 & 14 & 2.29 & Impaired soil biota (biodiversity) population growth, compacted soil \\
\hline \multicolumn{2}{|c|}{$\mathbf{X} 18.85$} & 2.17 & \\
\hline \multicolumn{2}{|c|}{ STD 11.24} & 0.32 & \\
\hline \multicolumn{2}{|c|}{ CV (\%) 60} & 15 & \\
\hline \multicolumn{2}{|c|}{ SE 2.51} & 0.07 & \\
\hline
\end{tabular}

*Data was obtain from Department of Soil Science Postgraduate Thesis Research Data Reserve, University of Abuja $\mathrm{X}=$ mean, $\mathrm{SD}=$ Standard deviation, $\mathrm{CV}=$ coefficient of variability, $\mathrm{SE}=$ Standard error 
compact then it could be stated that the soil has a limitation for increase biodiversity population, and for soil sustainable development in relation to agricultural usage and for environmental sustainability. The outcome of this study confirms the work of Pagliai (1988) who presented a view that soil with physical impairment like soil compaction could be an hindrance to soil microbial and soil biodiversity among other agrian uses of soil. The report of FAO (2006) indicated a view that with the increasing soil compaction soils become weak and vulnerable to biodiversity loss, with a grave impact on agricultural production, and playing a major in global food shortage and insecurity. Findings of this report further confirms the research of USDA (1999) who reported soil biodiversity been greatly hampered in compacted soils. Views of this finding also confirms the research outcome of Juan (1999) who reported decrease in soil microbes in compacted soils due to limited nutrient, air including moisture that is essential for biodiversity improvement.

Interaction of Soil Compaction on Soil Biodiversity

Data presented in Table 9.0 indicated that soil compaction inhibited the availability of earthworm which was used as a test microbes in the soil sample at the various locations. Although the Crystalline lattice nature of the soil compaction status showed that the area is poor in housing soil biota. But Site 11 and Site 15 presented Earthworm count of one (1). The poor microbial holding capacity of the soil could be linked to the compaction status of the soils. This finding agrees with the work of FAO (2006) which stated soil compaction as $\mathrm{n}$ hindrance to soil biodiversity and soil physical sustainability.

9. Interaction of Soil Compaction on Soil Biodiversity

\begin{tabular}{|c|c|c|c|}
\hline \multicolumn{4}{|c|}{ Soil compaction Interaction with Soil Biodiversity (Biota) } \\
\hline Location & Bulk density & $\begin{array}{l}\text { Micro-Morphological } \\
\text { Microscope View }\end{array}$ & $\begin{array}{l}\text { Magnifying hand-lens } \\
\text { View }\end{array}$ \\
\hline Code & $\left(\mathrm{gcm}^{-3}\right)$ & $\begin{array}{c}\text { Earthworm count } \\
\text { (length }=1 \mathrm{~cm})\end{array}$ & $\begin{array}{c}\text { Earthworm count } \\
(\text { length }=1 \mathrm{~cm})\end{array}$ \\
\hline 1 & 2.1 & 0 & 0 \\
\hline 2 & 2 & 0 & 0 \\
\hline 3 & 2.19 & 0 & 0 \\
\hline 4 & 1.64 & 0 & 0 \\
\hline 5 & 1.63 & 0 & 0 \\
\hline 6 & 2.27 & 0 & 0 \\
\hline 7 & 2.41 & 0 & 0 \\
\hline 8 & 2.19 & 0 & 0 \\
\hline 9 & 2.07 & 0 & 0 \\
\hline 10 & 2.5 & 0 & 0 \\
\hline 11 & 1.73 & 1 & 0 \\
\hline 12 & 2.19 & 0 & 0 \\
\hline 13 & 2.67 & 0 & 0 \\
\hline 14 & 2.45 & 0 & 0 \\
\hline 15 & 1.56 & 1 & 0 \\
\hline 16 & 2.18 & 0 & 0 \\
\hline 17 & 2.71 & 0 & 0 \\
\hline 18 & 2.31 & 0 & 0 \\
\hline 19 & 2.34 & 0 & 0 \\
\hline 20 & 2.29 & 0 & 0 \\
\hline $\mathbf{X}$ & & 0.10 & 0.00 \\
\hline STD & & 0.30 & 0.00 \\
\hline CV (\%) & & 300.00 & 0.00 \\
\hline SE & & 0.07 & 0.00 \\
\hline
\end{tabular}

*Earthworm was used as the basis for assessment of soil biota

$\mathrm{X}=$ mean, $\mathrm{SD}=$ Standard deviation, $\mathrm{CV}=$ coefficient of variability, $\mathrm{SE}=$ Standard error 
3.5 Digital Terrain Modeling (base map of the study location)

Data analysis output for the geo-referenced data (coordinates of the sites investigated) were modelled using the Quantum Geographic Information System (GIS) is presented in Figure 3, data analysis presents a view that the topography of University of Abuja ranges from gentle slope to undulating slope with some contour points and elevation reaches as high as $>564 \mathrm{~m}$ above sea level. Result of this finding confirms the research of FAO (2006) where her report indicated undulating slope points and high elevation in sub-Sharan Africa. The Digital Terrain Modeling presented a view that the University of Abuja landmass fall into different topo-sequence, hence collaborates the research of FCDA (2000) who reported the area been on a different topo-unit among other locations of the Federal Capital of Nigeria.

Conclusions. The outcome of the study revealed that soil compaction negatively affect the population of soil biota, thereby reducing soil biodiversity. The result of the study indicated that soil biota population reduces, as the impact in soil compaction increases. The coefficient of determination value of $13.5 \%$ indicated that the soil is compact which is an indication that root penetration could be hindered. Bulk density value range of $1.56 \mathrm{gcm}^{-3}-2.71 \mathrm{gcm}^{-3}$ was found to be too compact for sustainable soil biota development, while porosity value range of $1 \%-41 \%$ indicated tight soil spore that can imped soil biodiversity, and contribute food shortages and food insecurity. Outcome of this investigation concluded that proper tillage, application of fertilizer including organic matter be carried out for the study area soils and soils of its environs for sustainable crop production, and as a strategy for meeting food security.

Acknowledgement. We are grateful to the Department of Soil Science, University of Abuja for providing apparatus and enabling environment for back-up experiment and for providing secondary data used for this study. We also sincerely appreciate the Nigeria Institute of Soil Science (NISS) for providing facilities for internet which aided the compilation of this work

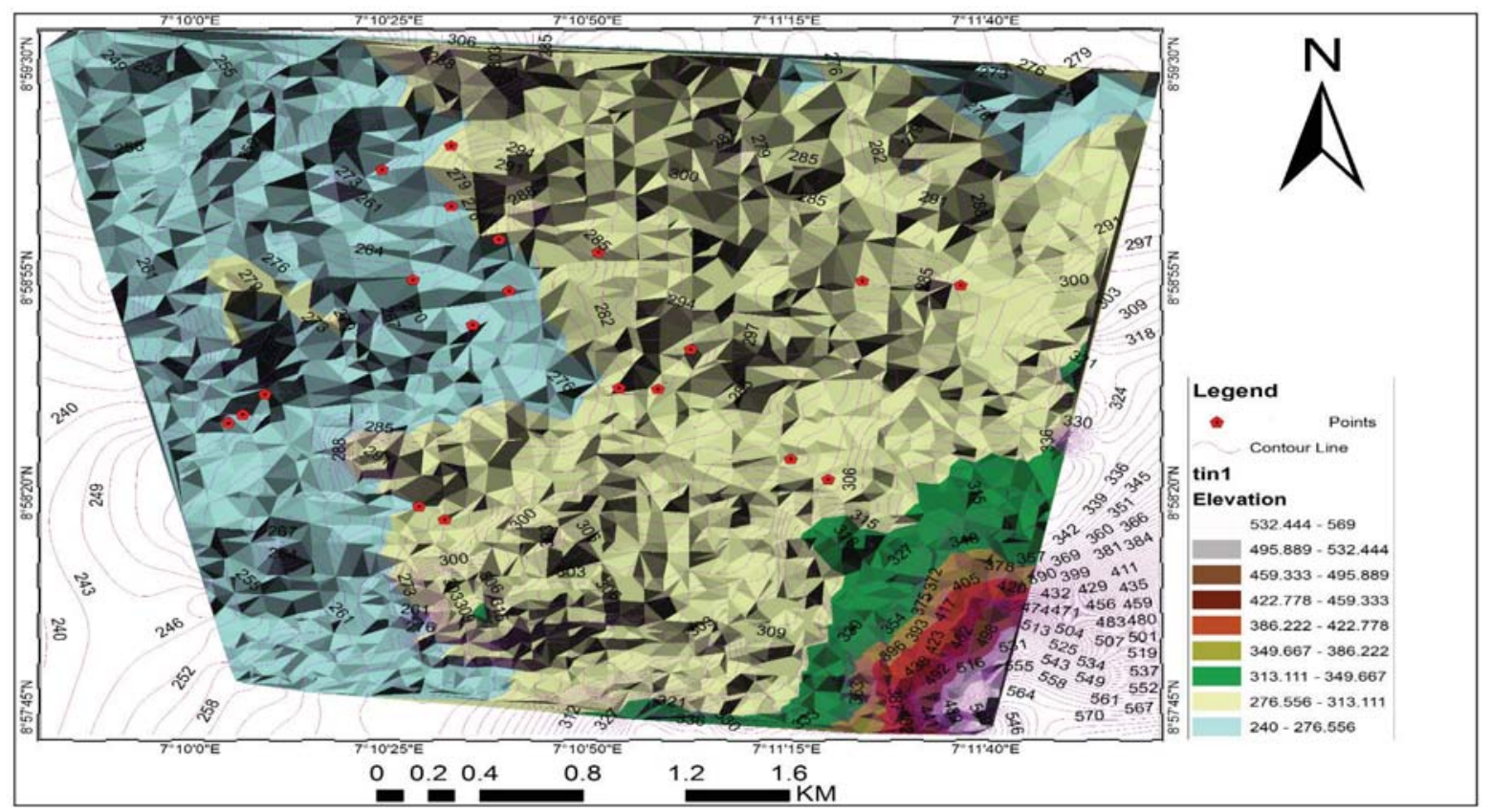

Fig. 3. Digital Terrain Modeling (base map of the study location)

\section{References}

1. Adiaha, M.S. (2016). Influence of different soil types and mineral fertilizer on maize (Zea mays L.) growth for effective production, soil fertility improvement and food security. International Scientific Journal: World Scientific News, WSN 55, 137-167

2. Adiaha, M.S., Buba, A H., Tangban, E.E, \& Okpoho, A.N (2020) Mitigating Global Greenhouse Gas Emission: The Role of Trees as a Clean Mechanism For CO2 Sequestration, The Journal of Agricultural Sciences, 15:1, 101-115. Retrieved from: http://doi.org/10.4038/jas.v15i1.8675 
3. Balogun, O. (2001).The federal capital territory of Nigeria: Geography of its Development. University of Ibadan. Nigeria: University of Ibadan Press.

4. Barros, M.E. (1999). Effet de la macrofaune sur la structure et les processus physiques du sol de paturages degrades d'Amazonie. Doctorate Thesis. University Paris.

5. FAO (Food and Agriculture Organization of the United Nations). (2000). Soil Survey Guide. FAO, Rome.

6. FAO. (Food and Agriculture Organization of the United Nations). (2006). Guideline for soil description. 4th edition. Rome

7. Federal Capital Development Authority, FCDA, (2000). The Geography of Abuja. Retrieved from: https://www.fcda.gov.ng/index.php/about-fcda/the-geography-of-abuja.

8. Gee, G.W. and Bauder, J.W. (1986). Particle size analysis. In: Arnold Klute (eds.). Method of Soil Analysis, Part 1-Physical and Mineralogical Methods. SSSA Book Seria 5, Madison, Wisconsin, USA, 383-412.

9. Grossman, R.B. and Reinsch, T.G. (2002). Bulk Density and Linear Extensibility. In: Dane, J.H. and Topp, G.C., Eds., Methods of Soil Analysis: Physical Methods, Part 4, Soil Science Society of America, Madison, 201-228.

10. Hågvar, S. (1994). Log-normal distribution of dominance as an indicator of stressed soil microarthropod communities? Acta Zoologica Fennica, 195, 71-80.

11. Hillel, D., (1982). Introduction to Soil Physics. San Diego, Academic Press.

12. Ishaya, S., (2013). Flood Vulnerability Mapping in Gwagwalada Urban Area, Abuja, Nigeria. Unpublished Master's Thesis, Department of Geography, University of Abuja, Nigeria.

13. Juan J. Jiménez and Patrick M. Lavelle References: Chauvel, A., Grimaldi, M., Barros, E., Blanchart, E., Desjardins, T., Sarrazin, M., and Lavelle, P. (1999). Pasture damage by an Amazonian earthworm. Nature, 398, 32-33.

14. McNeely, J.A., Gadgil, M., Leveque, C., Padoch, C. \& Redford, K. (1995). Human influences on biodiversity. In UNEP, ed. Global biodiversity assessment. Cambridge, UK, Cambridge University Press.

15. Oku, E.E., Babalola, O., \& Essoka, A.N. (2010). Profile distribution of some physical properties and infiltration behavior along a paleustalfs toposequence in south western Nigeria. Trop. Agric (Trinidad), Vol. 87, No. I .

16. Pagliai, M. (1988). Soil porosity aspects. Intern. Agrophysics, 4, 215-232.

17. Penn State Extension (2003). Effects of Soil Compaction. Retrieved from: https://extension. psu.edu/effects-of-soil-compaction

18. Radford, B.J., A.C.Wilson-Rummenie, G.B. Simpson, K.L. Bell, \& M.A. Ferguson. (2001). Compacted soil affects soil macrofauna populations in a semi-arid environment in central Queensland. Soil Biology \& Biochemistry, 33:1, 869-872.

19. USDA. (1999). Soil quality test kit guide. USDA Soil Quality Institute. Washington, D.C.

20. Breure, A.M. (2004) Soil Biodiversity: Measurements, Indicators, Threats and Soil Functions. Paper presented at the I International Conference Soil and Compost Eco-Biology September 15th 17th 2004, León - Spain

21. Greenbelt Consulting (2014). Environmental Management, Assessment, Mitigation, Restoration, Education \& Outreach http://www.greenbeltconsulting.com/articles/relationships.html (Retrieved, 29/3/2020)

22. Ali, Ashenafi, Esayas, Abayneh, Beyene, Sheleme, (2010). Characterizing soils of DelboWegen watershed, Wolaita Zone, southern Ethiopia, for planning appropriate land management. J. Soil Sci. Environ. Manage. 1 (8), 184-189.

23. Korres, W., Reichenau, T.G., Schneider, K., (2013). Patterns and scaling properties of surface soil moisture in agricultural landscape: an ecohydrological modeling study. J. Hydrol. 489, 89-102.

24. Fantaw, Yimer, Ledin, S., Abdelkadir, A., (2006). Soil property variations in relation to topographic aspect and vegetation community in south-eastern highlands of Ethiopia. For. Ecol. Manag. 232, 90-99.

25. Moore, I.D., Gessler, P.E., Nielsen, G.A., Peterson, G.A., (1993). Soil attributes prediction using terrain analysis. Soil Sci. Soc. Am. J. 57, 443-452.

26. Brubaker, S.C., Jones, A.J., Lewis, D.T., Frank, K., (1993). Soil properties associated with landscape positions. Soil Sci. Soc. Am. J. 57, 235-239.

27. Miller, P.M., Singer, M.J., Nielsen, D.R., (1988). Spatial variability of wheat yield and soil properties on complex hills. Soil Sci. Soc. Am. J. 52, 1133-1141. 
28. Mulugeta, Demis, Sheleme, Beyene, (2010). Characterization and classification of soils along toposequence in Kindo Koyewatershed in southern Ethiopia. East Afr. J. Sci. 4 (2), 65-77.

29. Sheleme, Beyene, (2011). Soil characterization along toposequence in Gununo area, southern Ethiopia. J. Sci. Dev. 1 (1), 31-39.

30. Wang, J., Fu, B., Qiu, Y., Chen, L., (2001). Soil nutrients in relation to land use and landscape position in semi-arid small catchment of the loess plateau in China. J. Arid Environ. 48, 537-550.

31. Kosmas, C., Gerontidis, S., Marathianou, M., (2000). The effect of land use change on soils and vegetation over various lithological formations on Lesvos (Greece). Catena 40, 51-68.

\section{В.О. Чуде, Е.Е. Оку, Г.І.С. Нвака, М.С. Адіаха Оцінка ущільнення грунтів як маніпулятивна стратегія для покращення їх біорізнома- ніття: підхід до виконання Цілей Сталого Розвитку (SDG) два та шість}

Анотація Швидке зростання погіршення стану трунту стало негативним наслідком глобального розвитку, виступаючи перешкодою для сталого розвитку сільського господарства та довкілля. Біорізноманіття трунтів відіграє вирішальну роль у стійкості екосистем, але все ж спостерігається його швидке погіршення, особливо через збільшення токсичного та хімічного забруднення грунтів, вітрової ерозії, включаючи сильні зливи, щьо руйнує структуру трунту та погіршує трунтову біоту. Дії, які сприяють зменшенню ущілььнення трунтів за рахунок обробітку трунту та застосування добрив відіграють головну роль у виробнищтві продуктів харчування, крім того, є частиною стратегії екологічної стійкості. Були проведені польові дослідження, де було досліджено стан ущільнення трунту. На двадияти (20) точках відбору проб зібрано зразки трунту в чотирикратній (4) повторюваності, використовуючи пропориійну стратифіковану методику випадкового відборупроб. Результати лабораторного аналізу показали високе ущільнення трунту. Результати лабораторного аналізу оиінювали за нормою стандартизації ФАО щодо впливу ущільнення на біорізноманіття трунтів. Результати показали високе ущільнення трунту з діапазоном значень обємної щільності

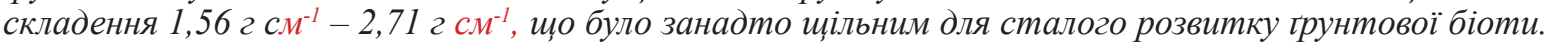
Було отримано діапазон значень пористості $1 \%$ - $41 \%$, що вказувало на щільну спорову структуру грунту, яка може перешкоджати біорізноманіттю трунту. Кореляційний аналіз $\left(R^{2}\right)$ виявив позитивну залежність (кореляцію) між рельєфом та ущільненням трунтів, причому результати ранжування грунтів були досить бідними щодо біорізноманіття (навантаження біоти). Результати ивого дослідження дали можливість зробити висновок, що для досліджуваних і прилеглих трунтів слід проводити належну обробку трунту, вносити добрива, включаючи органічні речовини.

Ключові слова: біорізноманіття; стійкість трунту; ущільнення трунтів; глобальний розвиток, иілі сталого розвитку.

\section{Оценка уплотнения грунтов как манипул Мная стратегия для улучшения их биораз- нообразия: подход к выполнению Целей Устойчивого Развития (SDG) два и шесть}

Аннотация Быстрый рост ухудшения состояния почвы стал негативным последствием глобального развития, выступая препятствием для устойчивого развития сельского хозяйства и окружающей среды. Биоразнообразие почв играет решающую роль в устойчивости экосистем, но все же наблюдается его быстрое ухудшение, особенно из-за увеличения токсического и химического загрязнения почв, ветровой эрозии, включая сильные ливни, разрушает структуру почвы и ухудшает почвенную биоту. Действия, которые способствуют уменьшению уплотнения грунтов за счет обработки и применения удобрений играют главную роль в производстве продуктов питания, кроме того, является частью стратегии экологической устойчивости. Были проведены полевые исследования, где было исследовано состояние уплотнения почвы. На двадиати (20) точках отбора проб собраны образиы почвы в четырехкратной (4) повторяемости, используя пропорииональную нестратифицированную методику случайного отбора проб. Результаты лабораторного анализа показали высокое уплотнение почвы. Результаты лабораторного анализа оценивали по норме стандартизаиии ФАО о влиянии уплотнения на биоразнообразие почв. Результаты показали высокое уплотнение почвы с диапазоном значений объемной плотности сложения 1,56 г $\mathrm{cm}^{-1}-2,71$ г $\mathrm{cm}^{-1}$, было слишком плотнылм дляустойчивого развития почвеннойбиоты. Было получено диапазон значений пористости 1\%-41\%, что указывало на плотную споровую структуру почвы, которая может препятствовать биоразнообразию почвы. Корреляционный анализ (R2) обнаружил положсттельную зависимость (корреляцию) между рельефом и уплотнением грунтов, причем результаты ранжирования почв были достаточно бедными по биоразнообразию (нагрузка по биоте). Результаты этого исследования позволили сделать вывод, что для исследуемых и прилегающих почв следует проводить надлежамую обработку почвы, вносить удобрения, включая органические вещества.

Ключевые слова: биоразнообразие; устойчивость почвы; уплотнения почв; глобальное развитие, цели устойчивого развития. 